\title{
Social media and teacher professionalism: Getting in on the act
}

\author{
Donna Pendergast ${ }^{1}$, Beryl Exley ${ }^{2}$, Nan Bahr ${ }^{3}$ and Jo-Anne Ferreira ${ }^{4}$
}

\section{Introduction}

On 24 September 2018 a commentary entitled Teachers are NOT underqualified and NOT undereducated: here's what is really happening, was published on the Australian Association for Research in Education (AARE) blog. It attracted the most interest of any blog ever published on the site with more than 11000 readers and many shares through social media on Facebook, Twitter, WordPress, Linkedin and Reddit (AARE, 2018). The article directly refuted claims by policy makers and more generally the media and the wider community about professional issues related to teachers and their work. Importantly, the article made the claim that "Australian teachers are doing well. They are not under qualified and they are certainly not under educated" (Bahr, Pendergast \& Ferreira, 2018) and built a series or arguments to defend this position.

This blog is one of several online publications in 2018 by the chapter authorship team to directly contest assumptions about the teaching profession. Earlier in 2018 and this time in a broader media space rather than one dedicated to education, on 16 April Bahr and Ferreira's (2018) article entitled Seven reasons people no longer want to be teachers was published by The Conversation. Shortly following this, on 20 April, Pendergast and Exley's (2018) article entitled Teachers can earn more than dentists ... and other reasons to enter the profession was published by ABC Online. This article was designed as a direct response to the Bahr and Ferreira (2018) online publication. Both publications were read and shared extensively to a broad audience.

As academics we are committed to publishing research as an important part of our work. Indeed publishing for impact is regarded as a crucial part of the work of members of the academy. However, engaging in social media commentary style publication remains a relatively new way of considering the notion of impact and certainly one that remains contested in terms of a range of issues such as: its validity, ethics, perceptions of self-promotion, potential impact on workload, balance between information and entertainment, to name a few of the complexities around publishing in this medium. Lupton's (2014) study of over 700 academics further revealed tensions in relation to boundaries between the professional (work) and the personal (life), and the role of academics in a medium that enables participatory democracy of thought.

Given this context we set out to achieve the following in this chapter. First, we consider the key elements of the three featured commentaries in terms of what appears to interest the readership and therefore - to an extent - may be regarded as proxies for discussion about teacher professionalism in the wider community. Second, we explore the role and value of social media, drawing upon these recent blogs to consider how employing social media might be a strategy employed to raise

\footnotetext{
${ }^{1}$ School of Education and Professional Studies, Griffith University

Email: d.pendergast@griffith.edu.au

${ }^{2}$ School of Education and Professional Studies, Griffith University

b.exley@griffith.edu.au

${ }^{3}$ School of Education, Southern Cross University

Email: nan.bahr@scu.edu.au

${ }^{4}$ School of Education, Southern Cross University

Email: jo-anne.ferreira@scu.edu.au
} 
discussion about teacher education professionalism. We share numerical data about the commentaries in terms of readership data and sharing frequency, and reveal the breadth and scale of the written responses to the blogs. Finally, we look broadly to social media and the interactions with multiple stakeholders and the challenges and opportunities this makes available to the profession.

\section{Social media and the rise of secondary stakeholders}

Social media is a relatively new yet powerful means of communication for producing and transmitting assumptions about the teaching profession and teacher professionalism. Since the move away from print to digital communication, and the arrival of Web 2.0 technology towards the end of the first decade of the new millennium, literally millions of people throughout the world have access to a seemingly unlimited amount of press about others' assumptions on these topics. At the time of writing this manuscript, five popular English social media sites for Western audiences were Facebook, YouTube, Instagram, Twitter, and Reddit. The interactive features of Web 2.0 technology provides the means through which people could express assumptions on these topics. For this reason, social media is considered by many to be a vehicle of democracy because of the potential to foster "decentralized citizen control as opposed to hierarchical, elite control" (Meraz, 2009, p. 682).

Social media has multiple formats, all of which promote ties between users and mobilises information via a news sharing or discussion function. The popularity of these social media platforms is in part fuelled by their interactive formats, and their relatively limited barriers of entry (Meraz, 2009). Yet to attract attention, social media users need to build and maintain credibility in an era when accusations of fake news are aplenty (Smith, Kendall, Knighton \& Wright, 2018).

Despite these points of similarity across social media platforms, each social media platform has its own specialised social purpose and social structure (Halpern, Valenzuela \& Katz, 2017). Two commonly used social media platforms are Facebook and Twitter. They each carry their own measure of participation and thus concepts of efficacy. From a comparative viewpoint, Facebook users have 'friends', thus forming a relatively symmetrical relationship of reciprocity with other users. Twitter, on the other hand, operates with 'followers' who share a particular interest but without being required to reciprocate. In this way, Facebook is more attuned to multi-way social connectedness, whereas Twitter is more attuned to the one way sharing of information. Facebook's profiles are customized with personal information fields, whereas Twitter allows users greater anonymity (Halpern, et. al., 2017).

\section{The featured commentaries}

The three commentaries utilised in this chapter were all published in digital format online and were available to be re-posted and included in social media such as Twitter, Reddit and Facebook. Paper 1 was first published in the AARE Blog, Paper 2 in The Conversation, and Paper 3 in ABC News Online.

Paper 1, Teachers are not under-qualified and not under-educated: Here's what is really happening (Bahr, Pendergast \& Ferreira, 2018), was published on the AARE blog, EduResearch Matters. The blog was established in 2013 to connect Australian educational researchers directly to the broad audience of Australians who are interested in education, including parents, teachers, politicians and journalists. Around one post is published each week in everyday language. Articles published in the AARE blog include republish links to email, Facebook, Twitter and other social media.

Paper 2, Seven reasons people no longer want to be teachers (Bahr \& Ferreira, 2018), was published in The Conversation which was established in 2011 and aimed at "making the knowledge of scholars and researchers accessible to the general public by having journalists commission and edit analytical 
and opinion pieces written by academic experts - and delivering the resulting stories online. This turned out to be a new form of journalism" (The Conversation, 2017, p,3). In the 2017 Annual Report the largest month of individual users to come to The Conversation site was reported to be 6.7 million in the month of October. Articles published in The Conversation include republish links to email, Facebook, Twitter and other social media.

Paper 3, Teachers can earn more than dentists... and other reasons to enter the profession (Pendergast \& Exley, 2018), was published in ABC News Online which is part of the Australian Broadcasting Corporation (ABC) national news service in Australia produced by the News and Current Affairs division. The ABC was established in 1947 and online in 2010. In 2016, the average monthly reach of ABC Online in Australia was 7.6 million (ABC, 2016). Items published online include republish links to email, Facebook, Twitter and other social media.

The diversity of these publishing sites is of itself interesting in that the publishers chose whether they believed the article would be relevant and interesting to their audience, which would be expected to be different - but intersecting - audiences. AARE readers are more likely to be educators and those interested in education as members of the association and hence have direct access to the blog. The Conversation readers tend to be more educated than the general public as the concept behind this website is sharing academic research, even though the writing style makes it more accessible. ABC News Online readers are more likely to be educated than the general public, and looking for items that are news rather than information.

Table 1 provides an overview of the three social media publications we refer to in this chapter in order to firstly consider what appears to interest the readership and therefore may be regarded as proxies for discussion about teacher professionalism in the wider community; and secondly as a focus for exploring the role and value of social media with regard to the teaching profession.

Table 1 Details about the 3 social media publications

\begin{tabular}{|c|c|c|c|}
\hline Title & $\begin{array}{l}\text { Teachers are not under-qualified } \\
\text { and not under-educated: Here's } \\
\text { what is really happening }\end{array}$ & $\begin{array}{l}\text { Seven reasons people no longer } \\
\text { want to be teachers }\end{array}$ & $\begin{array}{l}\text { Teachers can earn more than } \\
\text { dentists... and other reasons to } \\
\text { enter the profession }\end{array}$ \\
\hline $\begin{array}{l}\text { Abbreviat } \\
\text { ion }\end{array}$ & Paper 1 & Paper 2 & Paper 3 \\
\hline Publisher & $\begin{array}{l}\text { Australian Association for } \\
\text { Research in Education (AARE) } \\
\text { Blog }\end{array}$ & The Conversation & ABC News Online \\
\hline Authors & Bahr, Pendergast and Ferreira & Bahr and Ferreira & Pendergast and Exley \\
\hline Date & $24 / 09 / 2018$ & $16 / 04 / 2018$ & $20 / 04 / 2018$ \\
\hline Links & $\begin{array}{l}\text { https://www.aare.edu.au/blog/? } \\
\text { p=3197 }\end{array}$ & $\begin{array}{l}\text { http://theconversation.com/seve } \\
\text { n-reasons-people-no-longer- } \\
\text { want-to-be-teachers-94580 } \\
\text { https://www.abc.net.au/news/20 } \\
\text { 18-04-16/seven-reasons-people- } \\
\text { no-longer-want-to-be- } \\
\text { teachers/9661878 }\end{array}$ & $\begin{array}{l}\text { https://www.abc.net.au/news/20 } \\
\text { 18-04-20/seven-reasons-people- } \\
\text { still-want-to-be- } \\
\underline{\text { teachers/9675864 }}\end{array}$ \\
\hline
\end{tabular}

\section{Analysing the papers and responder posts}

In order to consider the publications, we first analyse characteristics of the articles and second, the comments posted online in response to the articles. For the first stage, for each article, we consider: the title and opening paragraph and how this positions the article as positive, neutral or negative; the 
range of subject matter covered; the image/s accompanying the article; and the most frequent words used in the article. For the latter step we employ a method developed by Pendergast (2013) which involves the content being analysed for frequency to develop a taxonomy. Functional lemmas are removed (eg. is, that, were, are, and etc) and the remaining words are presented as word clouds with words presented in font size proportional to their frequency, with the larger text being terms used more often. This is presented as a word cloud for visual impact. Each of these characteristics of the content of the articles is analysed and reflections about how this might serve as a form of proxy about current interest in the teaching profession is proffered.

For the second stage we conduct an analysis of the comments posted in response to each article. Data about the posts such as the specified gender of the author; average posts per person; and an analysis of the frequency of terms used in the comments provides insight into the nature of the responses to the articles. Again we utilise Pendergast's (2013) method of text analysis to present word clouds visually representing the frequency of terms used. We also provide insight into the altmetrics of the social media sites.

\section{Findings}

Stage 1 of the analysis focused on the characteristics of the commentaries. The titles and opening sentences presented in Table 2 provide a summary of each and indicate clearly the valence (positive, neutral or negative) of what follows with regard to the teaching profession. Paper 1 and 3 are positive valence papers while Paper 2 is a negative valence paper. None of the papers were neutral.

Table 2 Title and opening sentences of the 3 social media publications referred to in this chapter

\begin{tabular}{|c|c|c|}
\hline Paper 1 & Paper 2 & Paper 3 \\
\hline $\begin{array}{l}\text { Teachers are not under-qualified } \\
\text { and not under-educated: Here's } \\
\text { what is really happening }\end{array}$ & $\begin{array}{l}\text { Seven reasons people no longer } \\
\text { want to be teachers }\end{array}$ & $\begin{array}{l}\text { Teachers can earn more than } \\
\text { dentists... and other reasons to } \\
\text { enter the profession }\end{array}$ \\
\hline $\begin{array}{l}\text { Australian teachers are doing well. } \\
\text { They are not under-qualified and they } \\
\text { are certainly not under-educated, as } \\
\text { some media stories would have you } \\
\text { believe. They are doing an admirable } \\
\text { job managing exhausting workloads } \\
\text { and constantly changing government } \\
\text { policies and processes. They are more } \\
\text { able than past generations to identify } \\
\text { and help students with wide ranging } \\
\text { needs. They are, indeed, far better } \\
\text { qualified and prepared than those in } \\
\text { our nation's glorious past that so many } \\
\text { commentators reminisce wistfully } \\
\text { about*. }\end{array}$ & $\begin{array}{l}\text { The oldest profession - teaching - is } \\
\text { no longer attractive. The Queensland } \\
\text { Deans of Education revealed there } \\
\text { have been alarming drops in first } \\
\text { preference applications for this year's } \\
\text { teacher preparation courses. } \\
\text { Queensland has experienced an } \\
\text { overall 26\% drop. Most alarmingly, } \\
\text { UQ reported a } 44 \% \text { plunge. QUT saw } \\
\text { a } 19 \% \text { drop. } \\
\text { These figures reflect a national trend. } \\
\text { ACU's is down } 20 \% \text { for campuses in } \\
\text { Queensland, New South Wales and } \\
\text { Victoria. This follows disappointing } \\
\text { interest in } 2017 \text {. VTAC reported a } \\
40 \% \text { drop in } 2017 \text { compared to } 2016 \text {. } \\
\text { So why don't people want to be } \\
\text { teachers anymore? There are at least } \\
\text { seven reasons people aren't so keen**. }\end{array}$ & $\begin{array}{l}\text { Teachers can earn more than dentists... } \\
\text { and other reasons to enter the } \\
\text { profession } \\
\text { Teaching is a complex profession, so } \\
\text { very dependent on the people who } \\
\text { take on the role of teachers. } \\
\text { Yes, the profession of teaching is at } \\
\text { another set of crossroads. One } \\
\text { certainty is that the profession of } \\
\text { teaching is not static; the rhythms of } \\
\text { the profession don't play the same tune } \\
\text { for long before another wave of } \\
\text { innovation hits the spotlight. } \\
\text { And given the importance of the work } \\
\text { of teachers, this is no surprise. } \\
\text { In their recent piece, Seven reasons } \\
\text { people no longer want to be teachers, } \\
\text { Nan Bahr and Jo-Anne Ferreira raised } \\
\text { a few points that warrant discussion } \\
\text { which, hopefully, can lift prospective } \\
\text { teachers out of the quicksand of } \\
\text { despair and toward a future of } \\
\text { opportunity and career fulfilment. }\end{array}$ \\
\hline
\end{tabular}




\begin{tabular}{|l|l|l|}
\hline & $\begin{array}{l}\text { Here, we acknowledge the ebb and } \\
\text { flow of teacherly life by identifying } \\
\text { seven new crossroads for aspiring } \\
\text { teachers but focusing the lens on why } \\
\text { people do choose to be teachers, and } \\
\text { why teaching is a most satisfying } \\
\text { career choice. }\end{array}$ \\
\hline
\end{tabular}

Source:

* Bahr, Pendergast \& Ferreira, 2018

** Bahr \& Ferreira, 2018

*** Pendergast \& Exley, 2018

Table 3 provides a summary of the content of the three papers. When looking across the content of the articles there is considerable overlap related to teacher education including references to entry, qualifications, and quality of programs. There is also overlap related to the teaching profession with a focus on negative perceptions including references to salary, public perceptions and workload. The content takes different directions, however, the issues remain relatively consistent.

Table 3 Analysis of the content of the 3 social media publications referred to in this chapter

\begin{tabular}{|c|c|c|c|}
\hline Title & $\begin{array}{l}\text { Teachers are not under- } \\
\text { qualified and not under- } \\
\text { educated: Here's what is really } \\
\text { happening }\end{array}$ & $\begin{array}{l}\text { Seven reasons people no longer } \\
\text { want to be teachers }\end{array}$ & $\begin{array}{l}\text { Teachers can earn more than } \\
\text { dentists... and other reasons to } \\
\text { enter the profession }\end{array}$ \\
\hline $\begin{array}{l}\text { Abbrevia } \\
\text { tion }\end{array}$ & Paper 1 & Paper 2 & Paper 3 \\
\hline Content & $\begin{array}{ll}\text { (Paragraph sections) } \\
\text { - } & \text { Teacher qualifications } \\
\text { - } & \text { Entrance to teacher education } \\
\text { - } & \text { Qurses } \\
\text { Quality of teacher education } \\
\text { courses and teacher educators } \\
\quad \text { Teacher workload }\end{array}$ & $\begin{array}{ll}\text { (Numbered reasons) } \\
\text { - } & \text { Teacher education } \\
\text { competency fixation } \\
\text { - } & \text { Standardised testing } \\
& \text { obsession } \\
\text { - } & \text { Lack of autonomy } \\
\text { - } & \text { Work intensification } \\
\text { - } & \text { Negative public images } \\
\text { - } & \text { Teacher bashing } \\
\text { - } & \text { Teachers' salaries are poor }\end{array}$ & $\begin{array}{l}\text { (Numbered reasons) } \\
\text { - We now ask them why they } \\
\text { want to be teachers } \\
\text { They need more } \\
\text { qualifications, but see } \\
\text { benefits } \\
\text { - The world-class national } \\
\text { curriculum does include } \\
\text { creativity } \\
\text { The pay's actually not bad } \\
\text { - Teachers rise above the } \\
\text { negativity } \\
\text { They're not just looking for a } \\
\text { fall-back (same as } 1 \text { ) } \\
\text { Teachers can influence others } \\
\text { to teach }\end{array}$ \\
\hline
\end{tabular}

When considering the content of the three papers, we present a series of word clouds that provide a visual presentation of the words used in the paper with their frequency represented by the relative font size. In generating the images words with three letters or fewer were removed and words with plurals and tenses have been matched so that, for example, teacher and teachers are combined as teacher; admin, administer, administered and administration are combined as administration. This word grouping is consistent with the methods outlined by Pendergast (2013).

Figures 1, 2 and 3 present the word clouds for the three papers with the greater frequency of words used represented in larger font. 
Figure 1 Paper 1 Word cloud with text size representing frequency

assesment AUStralia demonstrate cultural least keeping teacher-educa

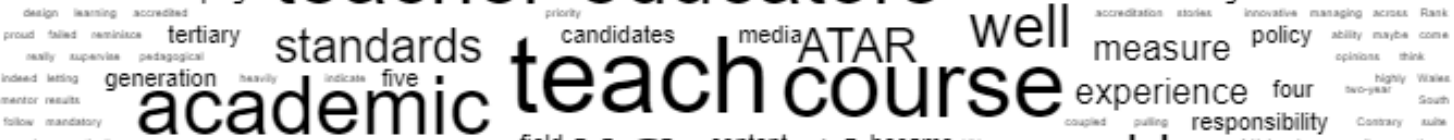

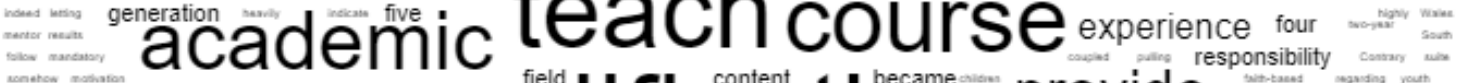

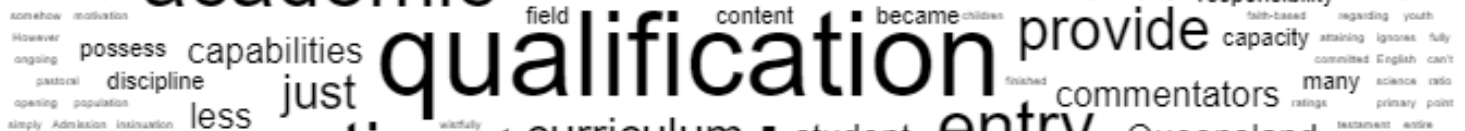

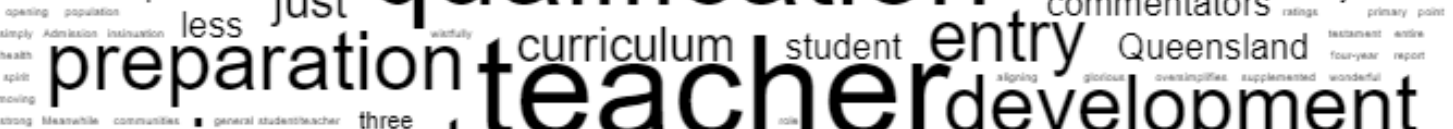
requiremênt teacherdevelopment

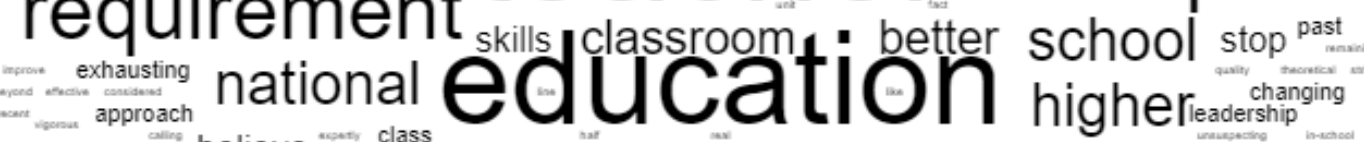
- belve yêrar

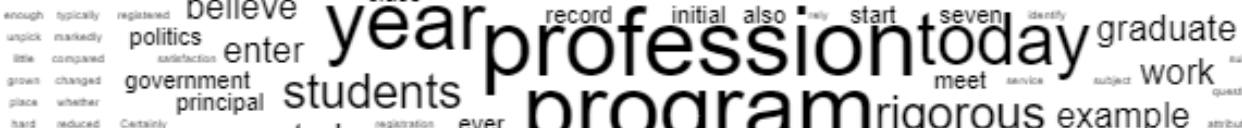

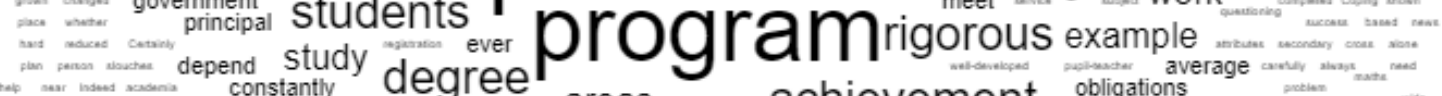
constantly degree areas must achievement obligations

Figure 2 Paper 2 Word cloud with text size representing frequency ans

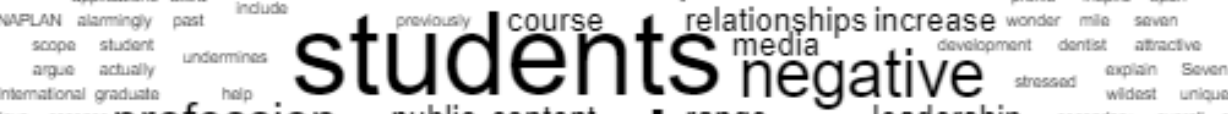

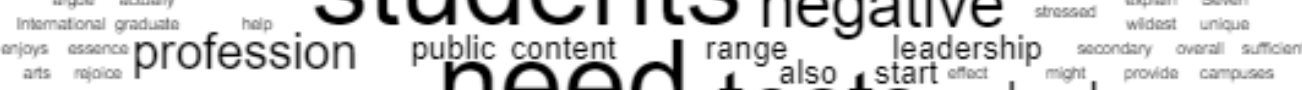

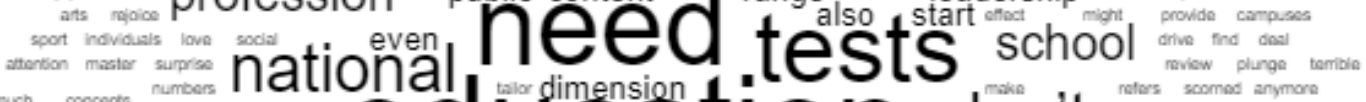
requirement time

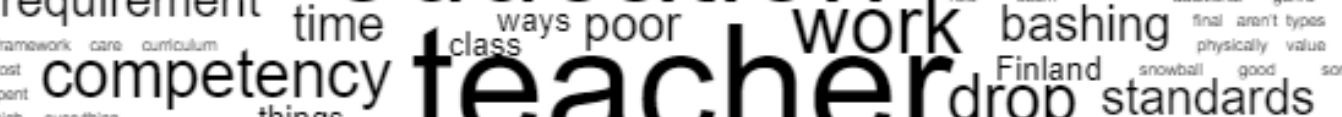

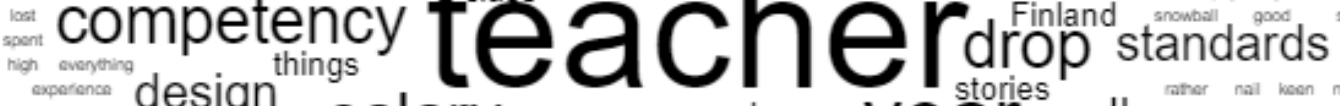

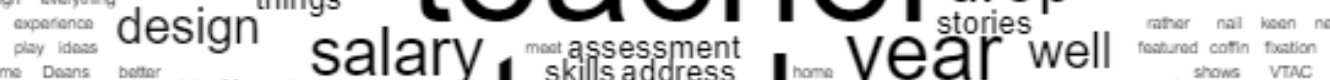
preparation Australia

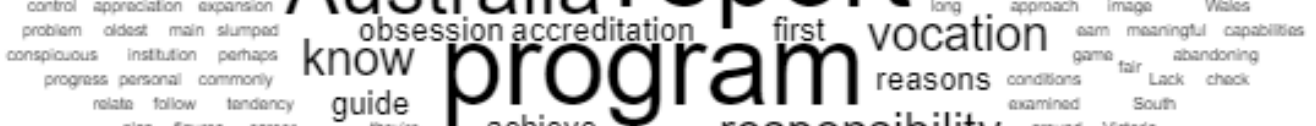
rolater tallow tentancy guide plan nganes carner guide 
Figure 3 Paper 3 Word cloud with text size representing frequency

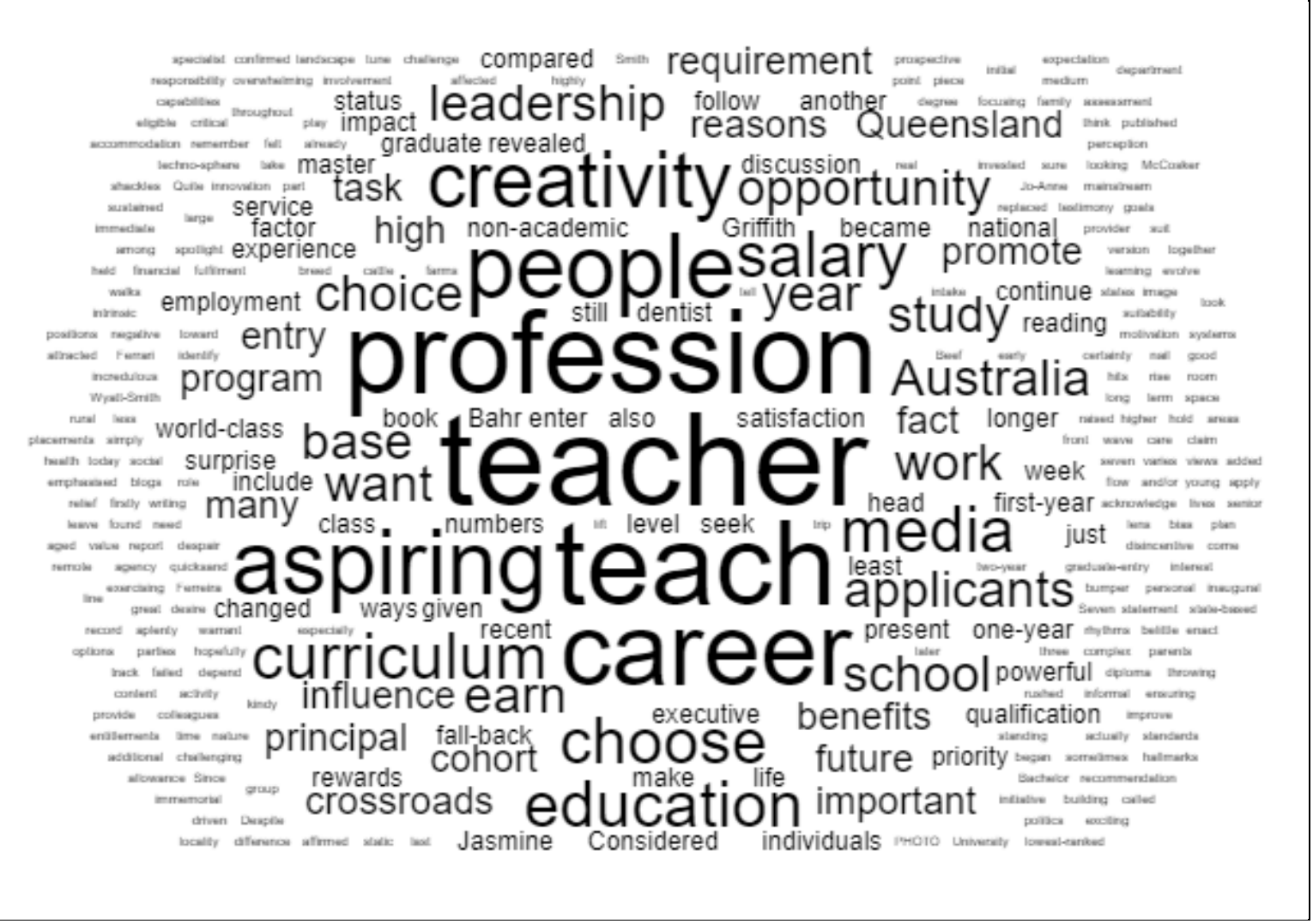

A summary of the most frequently used words across each of the papers is presented in Table 4, and quite unsurprisingly, the words teacher, teach and education feature as having high levels of usage in all three papers. The words need, tests and report feature in Paper 2, which takes a more negative stance about the teaching profession.

Table 4 Most frequent words used in Papers 1, 2 and 3 (alphabetical order, conjunctions removed)

\begin{tabular}{|l|r|r|r|}
\hline & Paper 1 & Paper 2 & Paper 3 \\
\hline aspiring & & & $1.05 \%$ \\
\hline career & & & $1.35 \%$ \\
\hline course & $1.04 \%$ & & \\
\hline education & $3.24 \%$ & $1.45 \%$ & \\
\hline need & & $1.27 \%$ & \\
\hline people & & & $1.05 \%$ \\
\hline profession & $1.04 \%$ & & $1.94 \%$ \\
\hline program & $1.04 \%$ & $1.27 \%$ & \\
\hline qualification & $1.43 \%$ & & \\
\hline report & & $1.27 \%$ & \\
\hline student & & $1.27 \%$ & \\
\hline teach & $1.30 \%$ & $2.91 \%$ & $3.74 \%$ \\
\hline teacher & $5.97 \%$ & $5.64 \%$ & $5.23 \%$ \\
\hline tests & & $1.09 \%$ & \\
\hline
\end{tabular}


The papers were each accompanied by images selected by the publishers without consultation with the authors. A summary of features of these images is presented in Table 5.

Table 5 Summary of images included in the Papers

\begin{tabular}{|c|c|c|c|}
\hline Paper & Description of image & Caption & Source \\
\hline 1 & $\begin{array}{l}\text { Close up of face of androgynous white, young } \\
\text { adult holding a whiteboard marker }\end{array}$ & $\begin{array}{l}\text { No caption - used as banner } \\
\text { image }\end{array}$ & stock \\
\hline \multirow[t]{2}{*}{2} & $\begin{array}{l}\text { White, female, older head on hand looking } \\
\text { tired and despondent }\end{array}$ & $\begin{array}{l}\text { Banner image with the text - } \\
\text { The programs are long and } \\
\text { intense, the creativity and } \\
\text { relationships aspect of the } \\
\text { vocation has been eroded, there } \\
\text { is pervasive negativity in the } \\
\text { media, and comparatively poor } \\
\text { salary and working conditions. }\end{array}$ & stock \\
\hline & Girl in uniform at desk alone writing & $\begin{array}{l}\text { Standardised tests, like } \\
\text { NAPLAN, contribute to lack of } \\
\text { enthusiasm to take up teaching. }\end{array}$ & stock \\
\hline \multirow[t]{3}{*}{3} & $\begin{array}{l}3 \text { children in uniform, sitting, raising hands, } \\
\text { no adults }\end{array}$ & $\begin{array}{l}\text { The inaugural Australian } \\
\text { Curriculum is futures driven, } \\
\text { exciting to teach and has all the } \\
\text { hallmarks of a world-class } \\
\text { curriculum. }\end{array}$ & original \\
\hline & $\begin{array}{l}\text { White, female, older teacher in big chair with } \\
\text { storybook and one child standing close by, } \\
\text { children sitting on floor observing reading }\end{array}$ & $\begin{array}{l}\text { Teacher Delena Clarke and } \\
\text { Jasmine Smith telling the } \\
\text { kindergarten class about what to } \\
\text { expect at Beef Week } 2015\end{array}$ & original \\
\hline & $\begin{array}{l}\text { White, male older teacher sitting at a flip chart } \\
\text { with children sitting on floor observing }\end{array}$ & $\begin{array}{l}\text { Grade } 1 \text { class at Fairfield Public } \\
\text { School }\end{array}$ & original \\
\hline
\end{tabular}

One of the reasons to incorporate images is the persuasive ability of images to reinforce the claims made in text (Hayne, 2018). Using Lister and Well's (2001, p. 77) "sociological concept of convention" and drawing on the "sign systems and codes ... of dress, style, architecture, objects, body language", the stock photos used in Papers 1 and 2 signal cultural markers of white middle class which perhaps says more about the editor of each site than the paper or the authors, given they had no influence on the selection of the images.

The ABC photos show both teachers and students in the same image and in two of the images the teachers are named, giving a sense of authenticity and newsworthiness to the image choice. While the majority of the students portrayed appear to be Caucasian, these photos do include teachers and students of different races, and for the most part, the children and teachers seem to be engaged and interacting. As Käpplinger (2015, p. 174) notes, these 'real' photographs "differ a lot from so-called stock photos, with their rather artificial atmospheres, although these might invoke the impression of 'professional' images".

For stage 2 we analysed the comments posted in response to the papers, a capacity enabled by the digital format which encourages participatory democracy. Table 6 provides a summary of the frequency and demographic information available for the posts (responder comments) made in response to each paper and the comment trail. This data is available for Papers 1 and 2 but not for Paper 3 as the ABC News Online social media site does not allow for audience comment. 
Table 6 Post frequency for Papers 1 and 2

\begin{tabular}{|l|c|c|c|c|c|}
\hline Paper & \multicolumn{2}{|c|}{ Paper 1 (AARE Blog) } & \multicolumn{2}{c|}{ Paper 2 (The Conversation) } \\
\hline $\begin{array}{l}\text { Number of } \\
\text { comments }\end{array}$ & \multicolumn{2}{|c|}{18} & & \\
\\
\hline $\begin{array}{l}\text { Unique number of } \\
\text { people commenting }\end{array}$ & \multicolumn{2}{|c|}{14} & & & \\
\hline Gender & $\mathrm{M}$ & $\mathrm{F}$ & $\mathrm{M}$ & $\mathrm{F}$ & $\mathrm{X}^{*}$ \\
\hline $\mathrm{N}(\%)$ & $6(43 \%)$ & $8(57 \%)$ & $61(65 \%)$ & $19(20 \%)$ & $14(15 \%)$ \\
\hline Number of posts & $9(50 \%)$ & $9(50 \%)$ & $154(59 \%)$ & $89(34 \%)$ & $18(7 \%)$ \\
\hline $\begin{array}{l}\text { Average posts per } \\
\text { person }\end{array}$ & 1.5 & 1.13 & 2.52 & 4.68 & 1.29 \\
\hline
\end{tabular}

*Gender not disclosed

Paper 1 published on the AARE blog attracted comments of almost equal proportion of male and female however males were more likely to add more than one comment. Paper 2 published on The Conversation had 261 comments made by 94 unique responders, of whom 65\% were male and just $20 \%$ female ( $15 \%$ did not disclose). However, on average female responders made more than double the number of comments (4.68) than males (2.52).

We also produced word clouds of the comments for each paper (Paper 3 ABC Inline did not have a comment facility so no word cloud is generated for this paper).

Figure 4 Paper 118 comments presented as word cloud with text size representing frequency

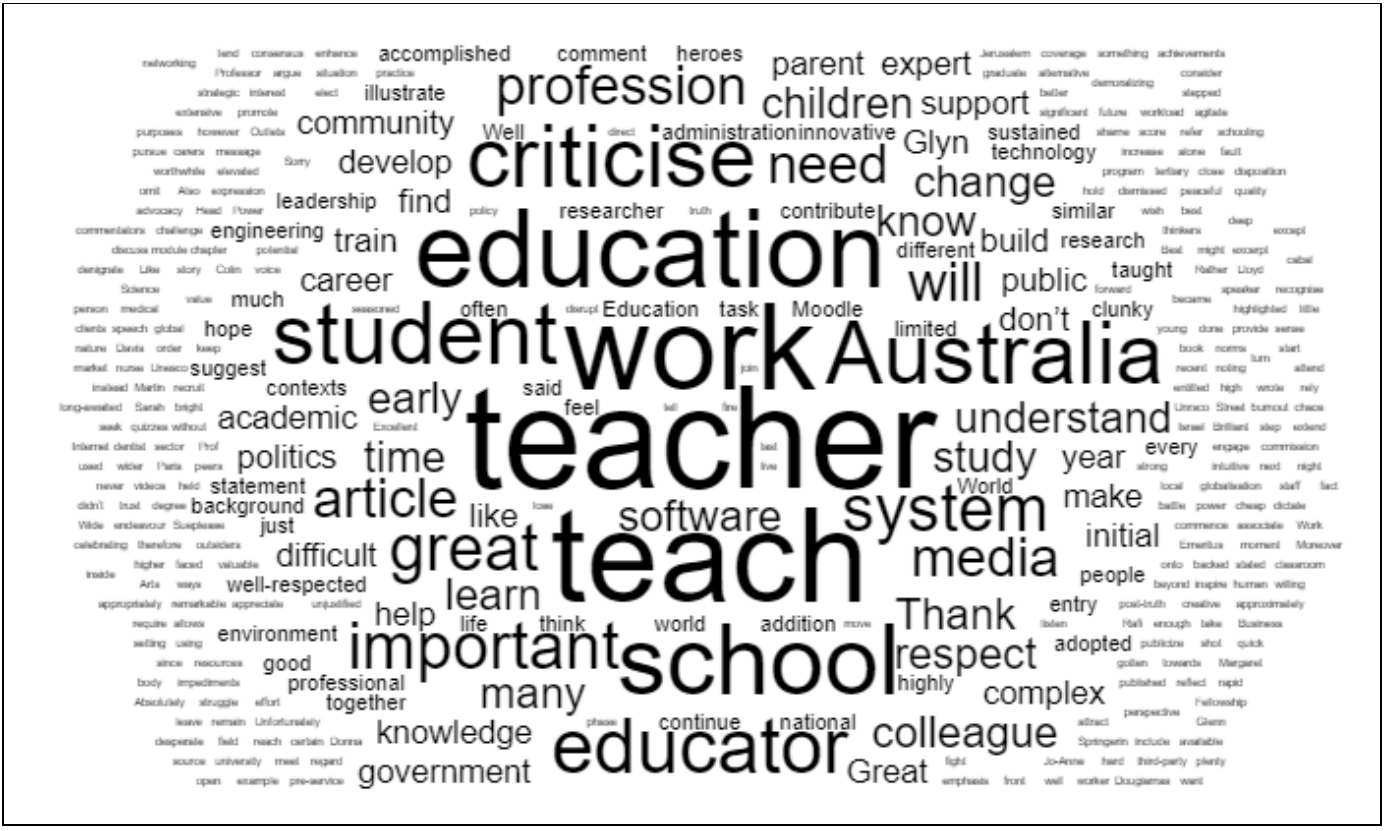




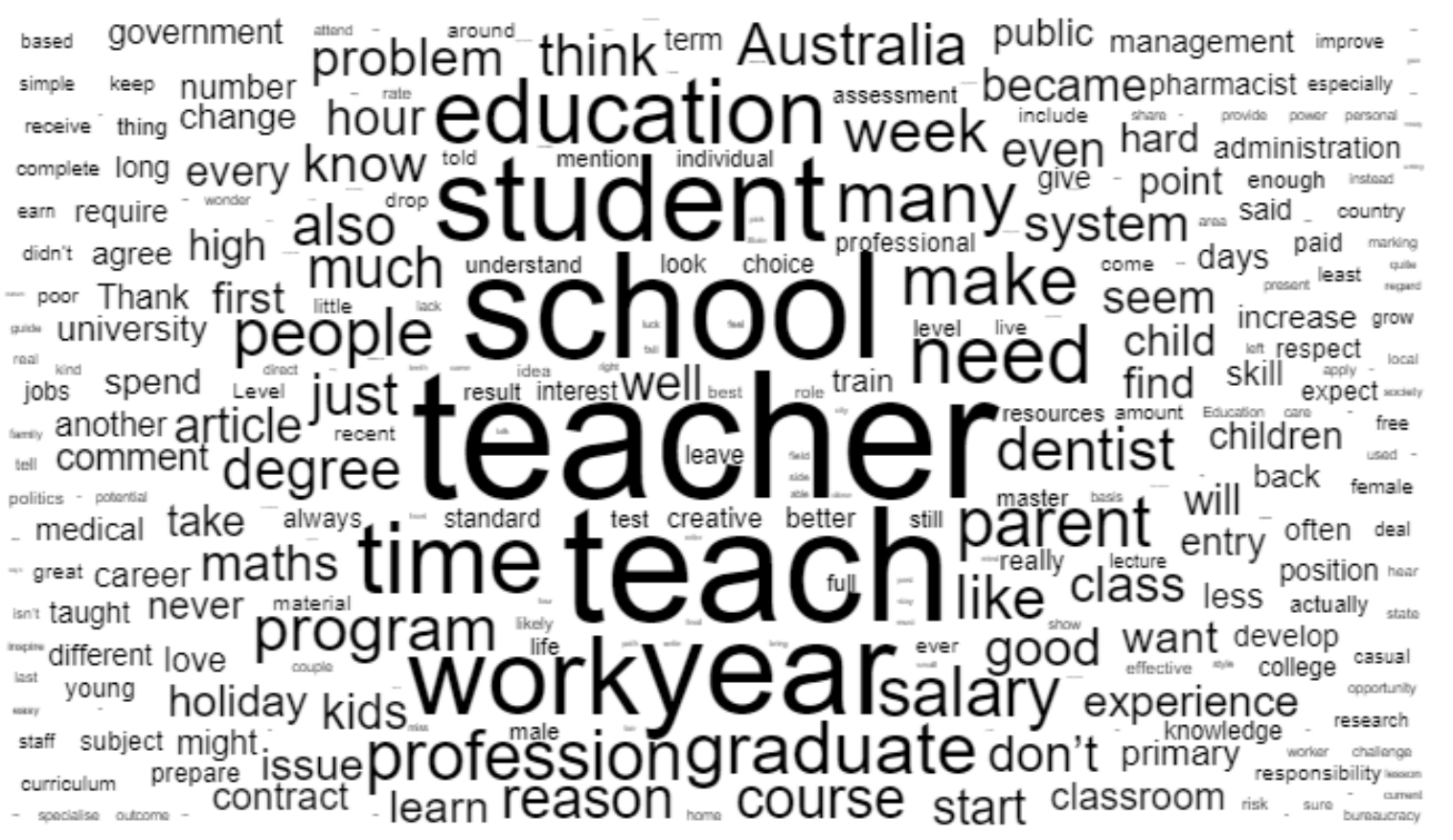

As presented in Table 6 and quite unsurprisingly, the words teacher, teach, school, student and education feature as having high levels of usage in the comments. The words great and criticise also feature, highlighting the dual nature of the responses.

Table 6 Most frequent words used in Paper 1 and Paper 2 comments (alphabetical order, conjunctions removed)

\begin{tabular}{|l|r|l|}
\hline Word & $\begin{array}{r}\text { Paper 1 } \\
\text { Comments }\end{array}$ & $\begin{array}{l}\text { Paper 2 } \\
\text { Comments }\end{array}$ \\
\hline Australia & $1.02 \%$ & \\
\hline criticise & $1.02 \%$ & \\
\hline education & $1.91 \%$ & \\
\hline great & $1.15 \%$ & \\
\hline school & $1.15 \%$ & $1.27 \%$ \\
\hline student & $1.02 \%$ & \\
\hline teach & $2.04 \%$ & $1.36 \%$ \\
\hline teacher & $4.83 \%$ & $2.76 \%$ \\
\hline work & $1.91 \%$ & \\
\hline year & & \\
\hline
\end{tabular}

Because of different publication sites and the availability of different analytic data, our information about the reach and impact of the papers is not directly comparable, nor is the source consistent, but a story can be told about each paper. Altmetrics data, that is the measure of attention articles receive online through social media such as Twitter, Facebook and Google, is partially available for each of the Papers, some sourced directly from the publisher. Altmetrics data is also complicated by the time of data collection, as the life of the publications continues indefinitely and hence the impact is 
constantly growing. For example, Paper 2 was published on April 16, 2018. By April 24, 2018, it had attracted 255,426 readers. It was "republished" 9 times through The Conversation site. The article was commented on through Twitter (117 tweets and retweets) and shared through Facebook (8400 shares). By 29 April the paper had 263,252 reads, 229 comments, 187 tweets and retweets, and 8,796 Facebook shares (Bahr, Graham, Ferreira, Lloyd \& Waters, 2018). A summary of altmetrics available at the time of preparing this chapter is presented in Table 8.

Table 8 Altmetrics data available for each paper

\begin{tabular}{|l|l|l|l|l|l|l|}
\hline Paper & Site & Twitter & Facebook & Views on day & Total views & Shares \\
\hline Paper 1 & AARE & $92^{\mathrm{d}}$ & $1 \mathrm{~K}+^{\mathrm{d}}$ & $6000^{\mathrm{a}}$ & $11,300+^{\mathrm{a}}$ & $1200^{\mathrm{a}}$ \\
\hline Paper 2 & Conversation & $187^{\mathrm{c}}$ & $8 \mathrm{~K}+^{\mathrm{c}}$ & & $310967^{\mathrm{c}}$ & $386^{\mathrm{b}}$ \\
\hline Paper 3 & ABC News & $27^{\mathrm{e}}$ & & & \\
\hline \\
a. According to AARE email \\
b. According to Bahr, Graham, Ferreira, Lloyd \& Waters (2018) \\
c According to The Conversation website \\
d According to AARE website \\
e According to \\
https://twitter.com/search?f=tweets\&q=Teachers\%20can\%20earn\%20more\%20than\%20dentists\%E2\%80\%A6\%20and\%20other \\
\%20reasons\%20to\%20enter\%20the\%20profession\&src=typd
\end{tabular}

\section{Discussion}

As the previous examples in this chapter demonstrate, primary stakeholders of the teaching profession (e.g. government regulators, teacher education providers, teacher employing authorities, teacher unions and so forth) no longer have an exclusive position as producers and transmitters of assumptions about teacher professionalism. With the coming of the social web, the asymmetry of influence of information and subsequent action has changed. A widening group of highly influential secondary stakeholders (e.g. the general public, activist groups, individual teachers, individual students, employer groups, publishing companies and so forth) have entered the public conversations. The secondary stakeholders are amassing huge audiences which they use as leverage for promoting counter assumptions and influencing change. The social media repositories gain their momentum by collecting multiple forms of evidence about a particular assumption. According to the research from Jurgens, Berthon, Edelman \& Pitt, (2016), sometimes it is the mass of evidence, rather than the weight of evidence, that can be used to advantage. In addition, secondary stakeholders can produce and transmit their own assumptions which implicate the power of primary stakeholders to maintain control of the agendas. Jurgens et al. (2016, p. 12) identify that secondary stakeholders now have (i) an increased ability to gather, analyse and share information, (ii) frame issues so as to garner greater appeal and a larger audience, and (iii) capitalise on the mobilising structures of the social web. These mobilising structures allow secondary stakeholders to reach and organise larger populations of people more rapidly, for linked networks to take action, and thus effect the production of assumptions at local and global levels.

The significant shifts in the ease and frequency of accessibility, the masses of people involved and society's increasing appetite for social media communication presents both challenges and opportunities for those trying to positively affect assumptions about teacher professionalism. Despite the widespread appeal of social media, many in the teaching profession do not actively contribute to this medium of communication. As we'll see, some contribute more than others. The next section overviews the reasons why some hesitate to get into the social media act. The final section considers existing and future opportunities for social media in positively affecting assumptions about teacher professionalism. 


\section{Challenges of getting into the social media act}

A number of reasons exist as to why it is a challenge for some stakeholders to get into the social media act.

The first challenge is that many teacher and school leadership stakeholders are forced into a passive position by their employers. By way of background, aside from our positions as teacher educators within universities, we four authors have all undertaken a range of volunteer positions with statebased and national teacher professional associations. In these forums, we often work alongside volunteer preservice teachers, teachers and school and system leaders. We are aware of the wave of activity on social media pertaining to the teaching profession and teacher professionalism. We appreciate the importance of canvassing and, at times, contributing to the social media conversations. We have all had firsthand experience with how time consuming and intellectually and emotionally exhausting these social media interactions can be. However, we are also struck by the reality that some of our industry colleagues feel as though they cannot publically contribute to these social media conversations. Despite being highly experienced and deeply knowledgeable teachers and school leaders, and indeed utterly committed to their profession and the topic of teacher professionalism, their workplace agreements institute codes of conduct that variously require employees to be impartial, promote the public good and publically commit to the system of government and the like. We also each know of individuals who have participated in some social media conversations about the teaching profession and teacher professionalism and have been reprimanded by line managers for doing so. Thus, workplace codes of conduct mean that many who might otherwise wish to contribute to the agendas on these topics are rendered voiceless. Their workplace codes of conduct limit them to the role of passive receivers of the assumptions that are being produced and transmitted by empowered primary and secondary stakeholders. There is an inherent issue when so many members of the profession have to rely on a smaller number of networked professionals (such as those who work in teacher education or teacher unions) to contribute conversations that represent the disparate voices of the profession. A question remains about how the profession can overcome this forced passivity.

The second challenge relates to personal risk. Those who have the right to enter into the social media conversations that produce assumptions about the teaching profession and teacher professionalism also do so with some risks. Like any public communication activity that requires one to make oneself 'manifest' through self-disclosure, there is risk of a disappointing outcome, a risk of loss of reputation or a risk of loss of network followers (Smith, et al., 2018).

The third challenge relates to the sophistication of the means of communication. To become involved, one must become proficient with a great range of social media communication strategies. Whilst on the surface social media communication seems efficient, it is not without its own sophisticated rhetorical strategies for constructing content and digital literacies for communicating content (Jurgens, et al., 2016). Ideograms, such as emojis, are not standardised language with all users. Their use is platform and culturally specific (Ge \& Gretzel, 2018). When adults involved in a social media conversation do not have the requisite confidence to use rhetorical strategies (Exley \& Willis, 2016) or the digital interface (Willis \& Exley, 2018), they may hesitate and thus withhold their contributions or make ineffective contributions. Similarly, if users do not subscribe to the social media language, their ideas will not resonate with the other social media consumers. Talking the language, so to speak, is of utmost importance for engaging within FaceBook or the twittersphere (Ge \& Gretzel, 2018).

A final challenge to be discussed in this chapter relates to the depth of the matter. Meraz (2009) comments that abstract issues are more difficult to transfer via social media when compared with more concrete issues. This is especially the case for micro-blogging platforms such as Twitter where communication is limited to 240 characters. This reality raises an epistemic matter for topics related 
to the teaching profession and teacher professionalism. If social media compromises abstract messages, and continues to give priority to easily reduced and communicated empirical messages, then, we contend, the discipline suffers. Bernstein (2000, p. 162) was quite clear on this point: It is only access through new ways of thinking that "new possibilities for a fresh perspective, access to new questions, a new set of connections, a new problematic and a new set of speakers' emerge. A longitudinal study into teachers' professional knowledge bases demonstrate that teachers bring deep theories and abstract thinking to their teacherly work (Exley, 2005). Thus relegating such weighty topics to a medium that might be only able to manage reductive assumptions may be counter to the mission of advancing the teaching profession and teacher professionalism.

\section{Opportunities for getting into the social media act}

In contrast to the challenges noted above, social media use brings multiple opportunities for changing assumptions about the teaching profession and teacher professionalism. The first benefit of people from the profession adopting social media use is the increased speed and convenience of communication. 'Liking', 'sharing' and 'tweeting' are all time efficient functions, so much so they have become part of human daily interaction for trillions of users (Brems et. al., 2017). Social media can also facilitate connections across settings, such as between the profession and the public, and between geographically dislocated members of the profession.

The second opportunity of people from the profession adopting social media use is that they can be closer to the pulse of assumptions held by a wide range of primary and secondary stakeholders (Ge \& Gretzel, 2016). Being closer to these more personal networks puts people from the profession in a better position to appreciate how others see the issues, and augments the likelihood of both learning about opportunities to participate, and being asked to participate in the production of professional assumptions (Halpern, et al., 2017). As a point of interest, Halpern et al's (2017) literature review identified studies that reported that when network size increases so too does a participant's probability of interacting with new information and/or following their friends' lead to engage in social action. This is an important point to consider when attempting to bring into relief topics that do not have wide spread uptake but are nonetheless important.

When people from the profession adopt social media use, a third opportunity arises, that of the potential to restore the balance of power around matters for the teaching profession and teacher professionalism. Instead of secondary stakeholders having the monopoly of power over the assumptions that are produced and transmitted, the agenda setting is in the hands of the people from the profession (Meraz, 2009). In this way, secondary stakeholders will struggle to be central gatekeepers over matters important to the profession. The people of the profession can collaborate to promote the profile of an individual who represents the collective cause. In spite of the seemingly chaotic fashion with which social media interactions take place, certain topics manage to get an inordinate amount of attention, thus bubbling to the top in terms of popularity and contributing to new trends for public and professional notice (Romero, 2011). Two compelling cases come to mind.

Recently, a mathematics teacher from Cherrybrook Technology High School in Sydney, Eddie Woo, won the Australia's Local Hero Award on the 25th January 2018. He was the first teacher to give the Australia Day address in New South Wales. In his address, Eddie spoke out about the teaching profession and matters that impact teaching professionalism: "Education has been one of Australia's greatest assets but things won't stay that way unless we give educators the cultural and capital support they need to do their jobs. Valuing education isn't about awards or accolades, it's much more about trust and respect" (Gock, 23 January, 2018). Vignettes of his address went viral and some ten months later, a google search for <Eddie Woo teacher> returns 3.35 million hits. Eddie Woo's professional facebook page has in excess of 10 thousand 'friends' and his twitter account, @ misterwootube, has 17 thousand followers. One twitter follower with the handle @mesterman tweeted to 
@misterwootube about a Head of Department Mathematics vacancy @OLMCParramatta, encouraging Eddie that staff at @OLMCParramatta would love to work with him. Another twitter follower with the handle @ KerrieQ tweeted that she 'felt blessed to have heard today's guest lecture @westernsydneyu for our pre-service teachers. Thank you for taking the time to inspire our new teachers'.

Gabbie Stroud, a former teacher, appeared on the ABC television panel show 'QandA' in early October 2018. Gabbie spoke about her passion for teaching, and the causes and effects of demoralisation and why she felt compelled to leave the teaching profession. Gabbie was scathing of the effects of standardised testing on the professional teaching standards. Gabbie lamented: "I think we're seeing a time where education in Australia, we must be getting close to rock bottom, because I think there are teachers that are suffering, there are students that are suffering..." (Bedo, 9 October, 2018). Within six weeks of her appearance on 'QandA' a google search for <Gabbie Stroud teacher $>$ returns 35 thousand hits. Gabbie Stroud's professional facebook page has in excess of three and a half thousand 'likes' and her twitter account @GJ_Stroud has inexcess of one and half thousand followers. One twitter follower with the handle @EducatorSTEM motivated @GJ_Stroud with the hashtag \#preachit. Another twitter follower with the handle @megsamanda, a music and digital technologies teacher, tweeted that she bought Gabbie's book as her birthday treat.

It would seem that monologues from Eddie Woo and Gabbie Stroud resonate with their followers, even though neither generates an inordinate amount of content on their social media profiles. Regardless, people of the profession have linked to Eddie Woo and Gabbie Stroud to automatically receive the content that they generate. In this way, Eddie Woo's and Gabbie Stroud's monologues are transformed into social dialogues. On this occasion, people of the profession were able to overcome the barrier of passivity and put these two advocates for the profession on pedestals. In doing so, the people of the profession have assisted in bringing two human faces to represent the work of teachers. These two advocates have come to represent a critical stakeholder group and bring into social dialogue matters pertaining to the teaching profession and teacher professionalism.

Smith et. al. (2018) purports that social media influencers demonstrate 'personality traits that include being verbal, smart, ambitious, productive and poised' (p. 10). Smith et. al. (2018) details research that shows that when individuals are officially or unofficially assigned as 'brand ambassadors', their personality traits carry over onto the brand and further influence the actions of others. For example, brand ambassadors often enter into mediation, gatekeeping, advocacy and/or boundary spanning roles for their respective associations (Smith et. al., 2017). Successful brand ambassadors, however, are unique. They are not necessarily 'created or developed' by the association, rather tending to 'selfselect into their organisation connection' (Smith et. al., 2018, p. 15). This good news story now leaves another challenge for the profession. When Eddie Woo and Gabbie Stroud self-select out of their brand ambassador roles, from where will our next brand ambassador come?

\section{Conclusion}

In this chapter we set out to consider the key elements of the three featured articles, looking towards high frequency word use in the articles and in comments alongside the key topics. We also reflected on the choice of images included in the papers. We then explored the role and value of social media drawing upon these recent publications to consider impact on the teacher professionalism context. Finally, we reflected more broadly on social media and the interactions with the multiple stakeholders of the challenges and opportunities of this form of engagement.

For the four of us, flirting with social media as a means to generate interest in, and challenge assumptions about, the teaching profession has been a departure from our mainstream academic publishing program. And it has been a rewarding departure. Most notably, the speed of reach to literally hundreds of thousands of readers is in deep contrast to the highly specialised readership of 
academic journals where we typically publish after a long and arduous peer review process that may take 12-18 months and our papers may be read by just hundreds. However, we must affirm that both have a place for us as academics. We also discovered that the challenge of the personal and the professional intersecting was also real for each of us as we received Facebook and Twitter feeds into our personal accounts, with both affirmations and criticism. The feedback from our colleagues and the wider community with an interest in the teaching profession has been phenomenal compared to feedback associated with our other academic work, with opportunities for follow-up interviews and speaking engagements flowing from interest in our papers. What we have learnt is that there is a place for publishing using social media, and we are keen to develop our capabilities in this space.

\section{References}

Australian Association for Research in Education (2018). Personal email communication Australian Broadcasting Commission (2016). ABC Annual Report, 2016. http://www.abc.net.au/corp/annual-report/2016/c2-online.html Accessed 21 December, 2018

Bahr, N. and Ferreira, J. (2018) Seven reasons people no longer want to be teachers. The Conversation, http://theconversation.com/seven-reasons-people-no-longer-want-to-be-teachers-94580 Accessed 21 November, 2018

Bahr, N., Graham, A., Ferreira, J., Lloyd, M., \& Waters, R. (2018). Promotion of the profession. Southern Cross University: Bilinga, Australia.

Bahr, N., Pendergast, D. and Ferreira, J. (2018). Teachers are NOT underqualified and NOT undereducated: here's what is really happening. Australian Association for Research in Education (AARE) blog, http://bit.ly/AARETeacherEd

Bedo, S. (9 October, 2018). Education experts lash out at Australian schooling system. News.com.au. Available from https://www.news.com.au/entertainment/tv/current-affairs/education-expertslash-out-at-australian-schooling-system/news-story/f9b159e4c0bc5f0ae44dee522776e559.

Bernstein, B. (2000). Pedagogy, Symbolic Control and Identity: Theory, Research, Critique. (Rev.ed.). Maryland, USA: Rowman \& Littlefield Publishers.

Brems, C., Temmerman, M., Graham, T. \& Broersma. M. (2017). Personal Branding on Twitter, Digital Journalism, 5:4, 443-459.

Exley, B. (2005). Teachers' Professional Knowledge Bases for Offshore Education: Two case studies of Western teachers working in Indonesia. Unpublished thesis, Queensland University of Technology.

Exley, B. \& Willis, L-D. (2016) Children's pedagogic rights in the web 2.0 era: A case study of a child's open access interactive travel blog. Global Studies of Childhood, 6, 4, 400-413.

Ge, J. \& Gretzel, U. (2018): Emoji rhetoric: a social media influencer perspective. Journal of Marketing Management, DOI: 10.1080/0267257X.2018.1483960

Gock, K. (23 January, 2018). A lesson from Eddie Woo: Be a mathematician on Australia Day. Sydney Morning Herald. Available from https://www.smh.com.au/national/nsw/a-lessonfrom-eddie-woo-be-a-mathematician-on-australia-day-20180123-h0mway.html.

Halpern, D., Valenzuela, S. \& Katz, J. (2017). We Face, I Tweet: How different social media influence political participation through collective and internal efficacy. Journal of ComputerMediated Communication, 22, 6, 320-336.

Hayne, J. (2018). How fake news can exploit pictures to make people believe lies. ABC News. Retrieved from https://www.abc.net.au/news/2018-11-22/fake-news-image-informationbelieve-anu/10517346

Jurgens, M., Berthon, P., Edelman, L, \& Pitt, L. (2016). Social media revolutions: The influence of secondary stakeholders. Business Horizons, 59, 129-136. 
Käpplinger, B. (2015). Addressing 21st Century Learners-A Comparative Analysis of Pictures and Images in Programs of Adult Education Providers in Canada and Germany. In Proceedings of the $34^{\text {th }}$ CASAE/ACEEA Annual Conference, Montreal. PP. 171-177

Lister, M., \& Wells, L. (2001). Seeing beyond belief: Cultural studies as an approach to analysing the visual. Handbook of visual analysis, 61-91.

Lupton, D. (2014) 'Feeling Better Connected': Academics' Use of Social Media. Canberra: News \& Media Research Centre, University of Canberra.

Meraz, S. (2018). Is there an elite hold? Traditional media to social media agenda setting influence in blog networks. Journal of Computer-Mediated Communication, 14, 682-707.

Pendergast, D. (2013). An appetite for home economics literacy:

Convergence, megatrends and big ideas. The Journal of Asian Regional Association for Home Economics.20(2), 57-65.

Pendergast, D. and Exley, B. (2018). Teachers can earn more than dentists ... and other reasons to enter the profession. ABC Online http://www.abc.net.au/news/2018-04-20/seven-reasonspeople-still-want-to-be-teachers/9675864

Smith, B., Kendall, M., Knighton, D. \& Wright, T. (2018). Rise of the brand ambassador: Social stake, corporate social responsibility and influencer among the social media influencers. Communication Management Review, 3, 1.

The Conversation (2017). The Conversation 2017 Annual Stakeholder Report: A year of record audience growth.

https://cdn.theconversation.com/static files/files/14/2017 Stakeholder Report The Convers ation.pdf?1518052945

Access 20 November, 2018.

Willis, L-D. \& Exley, B. (2018). Using an online social media space to engage parents in student learning in the early-years: Enablers and impediments. Digital Education Review, 33, 87-104. 